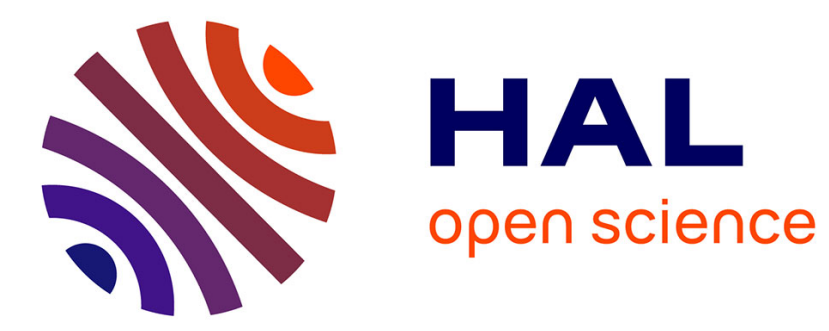

\title{
Effect of rare earth elements on rice plant growth
}

Raul Z. Martinez, Olivier Pourret, Michel-Pierre Faucon, Charlotte Dian

\section{To cite this version:}

Raul Z. Martinez, Olivier Pourret, Michel-Pierre Faucon, Charlotte Dian. Effect of rare earth elements on rice plant growth. Chemical Geology, 2018, 489, pp.28-37. 10.1016/j.chemgeo.2018.05.012 . hal02136358

\section{HAL Id: hal-02136358 \\ https://hal.science/hal-02136358}

Submitted on 22 May 2019

HAL is a multi-disciplinary open access archive for the deposit and dissemination of scientific research documents, whether they are published or not. The documents may come from teaching and research institutions in France or abroad, or from public or private research centers.
L'archive ouverte pluridisciplinaire HAL, est destinée au dépôt et à la diffusion de documents scientifiques de niveau recherche, publiés ou non, émanant des établissements d'enseignement et de recherche français ou étrangers, des laboratoires publics ou privés. 


\section{Accepted Manuscript}

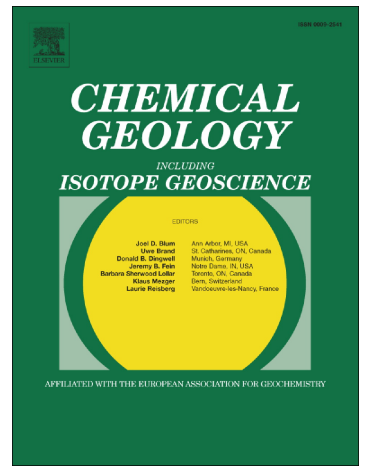

Raul E. Martinez, Olivier Pourret, Michel-Pierre Faucon, Charlotte Dian

PII: S0009-2541(18)30232-8

DOI: doi:10.1016/j.chemgeo.2018.05.012

Reference: CHEMGE 18765

To appear in: Chemical Geology

Received date: 5 October 2017

Revised date: 26 April 2018

Accepted date:

8 May 2018

Please cite this article as: Raul E. Martinez, Olivier Pourret, Michel-Pierre Faucon, Charlotte Dian, Effect of rare earth elements on rice plant growth. The address for the corresponding author was captured as affiliation for all authors. Please check if appropriate. Chemge(2017), doi:10.1016/j.chemgeo.2018.05.012

This is a PDF file of an unedited manuscript that has been accepted for publication. As a service to our customers we are providing this early version of the manuscript. The manuscript will undergo copyediting, typesetting, and review of the resulting proof before it is published in its final form. Please note that during the production process errors may be discovered which could affect the content, and all legal disclaimers that apply to the journal pertain. 


\section{Effect of rare earth elements on rice plant growth}

Raul E. Martinez ${ }^{1 *}$, Olivier Pourret ${ }^{2}$, Michel-Pierre Faucon $^{2}$, Charlotte Dian $^{1}$

${ }^{1}$ Institute for Earth and Environmental Science, Albert-Ludwigs University, Albertstrasse 23B, 79104, Freiburg, Germany

${ }^{2}$ UniLaSalle, AGHYLE, 19 rue Pierre Waguet, 60026, Beauvais, France

*Corresponding author:

Tel.: +49 7612036423

E-mail address: raul.martinez@minpet.uni-freiburg.de (R. E. Martinez)

Key words: rare earth elements, speciation, rice, root absorption, iron plaques, plant growth, iron (III) oxyhydroxides, chloride, sulfate 


\section{Abstract}

The goals of this study were, (1) to quantify the effects of rare earth elements (REE) on rice plant growth and (2) to determine whether the presence of iron (III) oxides on the plant root surface (i.e. the iron oxide plaques) played a role in impeding any toxic effects caused by the presence of the REE. Hydroponic experiments were designed to grow rice plants in a greenhouse under controlled conditions, exposed to all rare earth elements simultaneously, and to iron (II) sulfate or iron (II) chloride. The results showed a significant decrease in root and plant height and biomass at rare earth element concentrations of $0.5 \mathrm{mg} / \mathrm{L}$ and $1 \mathrm{mg} / \mathrm{L}$. Negative growth effects were observed for plant roots and shoots upon addition of 100 $\mu \mathrm{mol} / \mathrm{L} \mathrm{Fe}(\mathrm{II})$ chloride or $\mathrm{Fe}(\mathrm{II})$ sulfate. Even when the root biomass was enhanced upon addition of $\mathrm{Fe}$ (II) chloride at a $1 \mathrm{mg} / \mathrm{L}$ rare earth concentration, however, statistically significant decreases in root length and plant height were recorded. In the presence of Fe(II) sulfate, a negative growth effect was present for all REE concentrations, being more pronounced at the highest REE levels. . For the Fe(II) chloride experiments, speciation modeling showed that the rare earth elements would remain "free" as hydrated ions $\left(\mathrm{Ln}^{3+}\right)$ or would be complexed by Fe(III) oxyhydroxides. With Fe(II) chloride, the light rare earths (La, $\mathrm{Ce}, \mathrm{Pr}, \mathrm{Nd}$; LREE) remained mostly soluble, whereas the middle (Sm, Eu, Gd; MREE) and heavy (Gd, Tb, Dy, Ho, Er, Tm, Yb, Lu; HREE) elements were for the most part bound by Fe(III) solids. As negative growth effects were observed with Fe(II) chloride, the most soluble LREE could be concluded to play a role in rice plant growth inhibition. Furthermore, upon addition of $\mathrm{Fe}(\mathrm{II})$ sulfate, the MREE and HREE were significantly associated with $\mathrm{SO}_{4}{ }^{2-}$ and a regained toxic effect for rice plants was observed at the highest REE concentration, suggesting also an effect of the dissolved MREE-SO ${ }_{4}{ }^{+}$and $\mathrm{HREE}-\mathrm{SO}_{4}{ }^{+}$species on rice growth. This observation, coupled to the knowledge that $\mathrm{SO}_{4}{ }^{2-}$ is an essential nutrient for plants, suggests absorption of the REE-SO ${ }_{4}{ }^{+}$species by the rice plant. The recorded negative 
growth effects for both the Fe(II) chloride or Fe(II) sulfate conditions, strongly suggest that all REE are detrimental to the development of rice. For both the $\mathrm{Fe}(\mathrm{II})$ chloride and $\mathrm{Fe}(\mathrm{II})$ sulfate conditions the negative growth effects may have been attenuated as a consequence of REE sorption to $\mathrm{Fe}(\mathrm{III})$ oxyhydroxides (i.e. iron oxide plaques) identified on the root surface, as suggested by surface complexation modeling of the REE to iron (III) oxides, at the $\mathrm{pH}$ and ionic strength conditions in this study.

\section{Introduction}

Despite the growing concern on the environmental impact of an increasing use of the rare earth elements (REE) in agriculture, little information is available concerning the effects of REE on plant growth (d'Aquino et al., 2009). The uptake of REE by plant roots is the controlling step for the subsequent distribution, enrichment and fractionation of these elements in the aerial and edible plant parts, such as rice gains (Tagami and Uchida, 2006; Thomas et al., 2014; Pagano et al., 2015; Zhuang et al., 2017). In wheat roots, REE fractionation was shown to result from phosphate induced precipitation of the REE (Ding et al., 2006). Accumulation of REE in roots has led to inhibition of primary root elongation and decrease plant dry biomass, as well as a marked diminution in mineral nutrient content $(\mathrm{Hu}$ et al., 2002). In the aerial parts of rice plants, positive $\mathrm{Eu}$ and $\mathrm{Tb}$ anomalies were observed, as well as a positive Eu anomaly in rice roots (Tao et al., 2008). Ning and Xiao (1989) reported that REE at concentrations of less than $5 \mathrm{mg} / \mathrm{L}$ could enhance the growth of new rice roots, however, at higher REE contents growth inhibition in rice and other main crops has been demonstrated (Pang et al., 2002). The mechanisms controlling the transfer of REE to plant roots, however, are not yet properly identified and quantified. 
The transfer of the REE in soil-plant systems thus has been proposed to be intimately coupled with the Fe cycle (Brioschi et al., 2013). Iron has been shown to be essential for plant growth, suggesting the development of strategies by plants destined to maximize $\mathrm{Fe}$ absorption (Berner et al., 2003; Reichman and Parker, 2005; Robin et al., 2008). The proposed Fe/REE interaction in soils, however, would imply that the same processes that may mobilize iron in the rhizosphere (e.g. exudation of siderophores) may also target the REE (Wiche et al., 2016; Wiche and Heilmeier, 2016). The roots of wetland plants, such as those of rice, have been demonstrated to become covered largely by iron (III) oxide minerals, known as iron plaques (Fu et al., 2011; Yamaguchi et al., 2014). The mechanism of formation of these iron (III) minerals has not yet been fully quantified. However, iron plaques have been proposed to play a central role in the control of trace metal uptake by rice plants (Hansel et al., 2001; Batty et al., 2002; Hansel et al., 2002; Liu et al., 2005; Møller et al., 2008; Fu et al., 2011; Yamaguchi et al., 2014). However, the fate of the REE during the formation of plant root iron (III) minerals, as well as their form of interaction with the surface of these reactive solids, have not yet been fully quantified.

Physical and chemical weathering of rocks and their forming minerals are the source of the REE in the soil solution and in aquatic systems (Dia et al., 2000; Gaillardet et al., 2003; Pédrot et al., 2015; da Silva et al., 2017; Zhuang et al., 2017). The chemical reactions in these

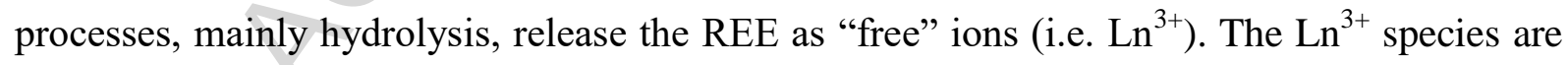
prompt to complexation by ligands in solution, such as carbonate, sulphate, soluble organic matter, colloids and solid surfaces such as Fe or Mn oxides (Guthrie et al., 2003; Tang and Johannesson, 2003; Wang et al., 2005; Liu et al., 2017). The partitioning of trace elements, including the REE, among available ligands is controlled by complexation stability constants, reaction kinetics, element concentrations and physicochemical parameters (e.g. pH, 
temperature) (Guthrie et al., 2003; Wang et al., 2005; da Silva et al., 2017; Zhuang et al., 2017). Quantifying the above parameters for REE organic and inorganic complexes is important to determine the concentration of the REE forms as a function of the reactive nature of dissolved ligands and solid phases. This is essential to understand the fate and interactions of these elements in aqueous environments, such as the rice root rhizosphere to quantify and identify the nature of the REE species which may detrimental to plant growth (Davranche et al., 2015; 2017).

In this study, rice plant growth was quantified in the presence of REE. Rice plants of the local Nep cai hoa vang Vietnamese variety were grown for a period of 14 days in hydroponic laboratory experiments. The plants were grown in: (1) the absence of REE (control conditions), (2) exposed to all REE from a standard solution at concentrations of 0.5 $\mathrm{mg} / \mathrm{L}$ and $1 \mathrm{mg} / \mathrm{L}$, and (3) in the presence of $100 \mu \mathrm{mol} / \mathrm{L} \mathrm{Fe}(\mathrm{II})$ chloride or $\mathrm{Fe}(\mathrm{II})$ sulfate and REE. The formation of REE sulfate complexes $\left(\mathrm{LnSO}_{4}{ }^{+}\right)$and amorphous iron (III) oxyhydroxide precipitates on the plant root, as determined by scanning electron microscopy and X-ray diffraction methods, played a key role in the solubility and absorption of the REE by the rice plant.

\section{Material and methods}

All chemicals used were of analytical grade. Ultrapure Mili-Q ${ }^{\circledR}$ water $(18 \mathrm{M} \Omega)$ was used for the preparation of rice growth medium and all solutions for chemical analyses. Unless stated otherwise. 
Whole grains of the local Nep cai hoa vang rice variety grown in the largest open-pit coal mining region in NE-Vietnam (Martinez et al., 2013), were acquired from the Quang Ninh Seedlings Joint Stock Company in Cam Pha and germinated under sterile conditions in a solution containing $0.049 \mathrm{~g} / \mathrm{L}$ of Murashige and Skoog medium basal salt mixture, $0.050 \mathrm{~g} / \mathrm{L}$ of MES (2-(Nmorpholino) ethanesulfonic acid) biological buffer, and $6 \mathrm{~g} / \mathrm{L}$ of phyto-agar. All three components were obtained from Duchefa Biochemicals (Haarlem, The Netherlands; product numbers: M0221.0025, M1503.0250, and P1003.1000, respectively). The $\mathrm{pH}$ of the resulting rice growth medium was adjusted to 5.7, with a sterile solution of $0.1 \mathrm{~mol} / \mathrm{L} \mathrm{NaOH}$, prior to the addition of phyto-agar and after addition of $\mathrm{Fe}(\mathrm{II})$ chloride or $\mathrm{Fe}(\mathrm{II})$ sulfate to the corresponding experimental set-ups. The $\mathrm{pH}$ was adjusted for optimal rice plant growth as suggested previously (Yoshida et al. 1976; Hoai et al. 2003; Martinez et al. 2013). The medium was subsequently sterilized by autoclaving at $121^{\circ} \mathrm{C}$ for $20 \mathrm{~min}$.

To test the effects of the REE on the growth of the Nep cai hoa vang variety, in the presence of $\mathrm{Fe}(\mathrm{II})$ sulfate and $\mathrm{Fe}(\mathrm{II})$ chloride, rice grains $(\mathrm{n}=533)$ were planted in sterile 15 $\mathrm{mL}$ Falcon ${ }^{\circledR}$ tubes, containing $12 \mathrm{~mL}$ of sterile rice growth medium, prepared as described previously (Martinez et al., 2013). The plants were grown in a greenhouse under controlled conditions with a humidity ranging from 80 to $90 \%$, at a temperature of 28 to $32^{\circ} \mathrm{C}$ and under a day/night cycle, with a 55000 to 60000 lux illumination for a period of 14 hours. The rice plants were harvested after a period of 14 days, and any excess agar was removed from the plant roots. After measurement of the root length, whole plants were dried to a constant weight in an oven at $60{ }^{\circ} \mathrm{C}$. This procedure was applied for control conditions, and for rice grains germinated in growth medium with a final concentration of $0.5 \mathrm{mg} / \mathrm{L}$ or $1 \mathrm{mg} / \mathrm{L}$ of all REE, exposed to $100 \mu \mathrm{mol} / \mathrm{L}$ of $\mathrm{Fe}(\mathrm{II})$ chloride or $\mathrm{Fe}(\mathrm{II})$ sulfate. Although iron has been shown to cause toxicity to rice plants, the final concentration of $\mathrm{Fe}$ in these experiments (i.e. 
$600 \mu \mathrm{mol} / \mathrm{L}$, of which $500 \mu \mathrm{mol} / \mathrm{L}$ are contained in the optimal growth medium), would at most exert non-significant toxic effect, when compared to those of toxic trace elements (Sahrawat, 2005). The final amounts of all the REE were obtained by dilution of a mutlicomponent standard solution containing an initial concentration of $50 \mathrm{mg} / \mathrm{L}$ in $2 \% \mathrm{HNO}_{3}$ of all the REE (CRM TraceCERT® Sigma-Aldrich Rare earth 16 element mix for ICP). The extent of the rice plant growth under these different experimental conditions was quantified by measuring the dry weight and the length of the wet roots and shoots, as suggested previously (Gardea-Torresdey et al., 2004; Bashan and de-Bashan, 2005; Martinez et al., 2013). The wet rice root length was manually measured using a digital caliper (Mitutoyo® Digimatic $150 \mathrm{~mm}$ ), as young rice plants after 14 days of growth, the root system was a single unbranched root whose length was quantifiable by a manual method as suggested previously (Himmelbauer et al., 2004; Muehe et al. 2014).

\subsection{Analytical setups}

To determine metal concentration in shoots and roots, $0.5 \mathrm{~g}$ (accurately weighed) of samples were digested using a mixture of $8 \mathrm{~mL} \mathrm{HNO}_{3}$ and $2 \mathrm{~mL} \mathrm{HCl}$ and a microwave system at the University of Freiburg (MLS GmbH Microwave Laboratory System, Germany) according to the procedure reported by Avula et al. (2010). Rare earth element concentrations in the digest samples were determined by Inductively Coupled Plasma Mass Spectrometry (ICP-MS) (Thermo Scientific XSERIES2) at UniLaSalle, Beauvais, France. Quantification was carried out by external calibration (REE multi elemental standard solution from Accu Trace Reference, USA) and using indium $(2.5 \mu \mathrm{g} / \mathrm{L})$ as an internal standard in order to correct for instrumental drift and matrix effects. The instrumental accuracy was assessed by analyzing the SPS-SW2 certified reference material (CRM) for measurement of elements in surface water (SpectraPur standards, Oslo, Norway). The analyses of real samples were carried out 
provided that the bias of measured concentration was $<5 \%$ compared to the certified values. The method for plants analysis was validated by the analysis of CRM 1573a - Tomato Leaves (NIST, Gaithersburg, USA). In addition, statistical agreement with the "determined but not certified data" for La, Ce, Sm and Gd was obtained.

\subsection{Mineralogical investigations.}

A qualitative mineralogical analysis of the root samples was carried out by using a Bruker AXS D8 Advance X-ray powder diffractometer, equipped with a $\mathrm{Cu}-\mathrm{K} \alpha$ radiation source, a diffracted-beam graphite monochromator, and a scintillation detector. The X-ray diffraction (XRD) patterns were collected from 2.0 to $60.0^{\circ} 2 \theta$, with a step size of $0.02^{\circ} 2 \theta$, and a dwell time of $2 \mathrm{~s}$ at each step. The patterns were evaluated with the DIFFRACplus 5.0 software. Iron (III) oxyhydroxides on rice plant roots were by using an environmental Scanning Electron Microscope (ESEM) (ElectroScan 2020) and a Quanta 250 FEG (FEI).

\subsection{Statistical analysis.}

Descriptive statistics were performed on shoot and root samples and normality of data and homogeneity of variances were verified. One-way ANOVA (Analysis of Variance) tested differences in metal concentrations in roots and shoots among rice plants exposed to REE, and Fe (II) chloride or Fe (II) sulfate. Post-hoc multiple comparisons (Tukey HSD) were applied after ANOVA when there was a significant difference (as expressed by the different letter labels, a, b and c, in Fig. 1 and Fig. 2)

\subsection{Speciation modeling.}

The speciation calculations were performed using the computer program PHREEQC version 3.1.5 (Parkhurst and Appelo, 2013) and the NAGRA/PSI data base (Hummel et al., 2002) 
modified to include well-accepted infinite-dilution $\left(25^{\circ} \mathrm{C}\right)$ stability constants for REE inorganic complexes (i.e., in our study, chlorides (Luo and Byrne, 2001) and sulfates (Schijf and Byrne, 2004). Surface complexation of the REE with hydrous ferric oxides (HFO) was modeled as described by Liu et al. (2017).

\section{Results and discussion}

\subsection{Effects of the REE on rice plant growth}

Fig. 1 and Fig. 2 show the results of rice plants grown exposed to $0.5 \mathrm{mg} / \mathrm{L}$ or $1 \mathrm{mg} / \mathrm{L}$ REE, and $100 \mu \mathrm{mol} / \mathrm{L} \mathrm{Fe}$ (II) chloride or Fe(II) sulfate. In the absence of added Fe(II) salts, the REE concentrations of $0.5 \mathrm{mg} / \mathrm{L}$ and $1 \mathrm{mg} / \mathrm{L}$ result in a significant decrease in root length and plant height and respective biomass (Fig. 1 and Fig. 2). The root length decreased from an average of $85 \pm 10 \mathrm{~mm}$ for control conditions to a mean of $45 \pm 10 \mathrm{~mm}$ for a REE concentration of $1 \mathrm{mg} / \mathrm{L}$ (Fig. 1). Similarly, the average root biomass diminished from $35 \pm$ $10 \mathrm{mg}$ for the control to $20 \pm 10 \mathrm{mg}$ at the highest REE content (Fig. 2). Detrimental growth effects for plant shoots are shown in Fig. 1 and Fig. 2. The plant height was reduced from 200 $\pm 50 \mathrm{~mm}$ under control conditions to $150 \pm 50 \mathrm{~mm}$ at $1 \mathrm{mg} / \mathrm{L}$ of REE (Fig. 1) and the shoot biomass diminished to $60 \pm 20 \mathrm{mg}$ from a control value of $85 \pm 15 \mathrm{mg}$ (Fig. 2). These results indicate a negative effect of the REE on rice growth at concentrations lower than those previously reported, where the negative plant growth effects of the REE were apparent at levels in excess of $5 \mathrm{mg} / \mathrm{L}$ (Pang et al., 2002). This suggests that the toxic effects of these elements are controlled by their speciation in solution and partitioning among specific organic and inorganic ligands, and reactive solids. These processes may facilitate root absorption of the REE, and further imply that the form of the REE species rather than their total nominal 
dissolved concentrations in the aquatic environment, would account for detrimental plant growth (Ichihashi et al., 1992; Tang et al., 2003).

\subsection{Speciation of the REE with $\mathrm{Fe}(I I)$ chloride or $\mathrm{Fe}(\mathrm{II})$ sulfate and effects on rice growth}

In aquatic systems, such as the plant rhizosphere, solution and interface chemistry is the controlling factor determining the dominant dissolved REE species and their concentrations (Sholkovitz, 1995; Davranche et al., 2015; 2017). Speciation calculations for the REE in the presence of Fe(II) chloride are shown in Fig. 3a. As reported previously, in the presence of chloride, $\mathrm{LnCl}^{2+}$ and $\mathrm{LnCl}_{2}^{+}$are the dominant species below a $\mathrm{pH}$ of 5 , however at the $\mathrm{pH}$ of the experiments herein, the concentrations of these species is negligible (i.e. $<0.1 \%$ ) (Brookins, 1989). With the addition of $100 \mu \mathrm{mol} / \mathrm{L} \mathrm{Fe}(\mathrm{II})$ chloride, 90 to $70 \%$ of the light rare earth elements (LREE: La, Ce, Pr, Nd) are present as "free" hydrated ions, whereas $70 \%$ of the middle (MREE: Sm, Eu, Gd) and $70 \%$ to $80 \%$ of the heavy elements (HREE: Gd, Tb, Dy, Ho, Er, Tm, Yb, Lu) are bound by hydrous ferric oxides (HFO) (Fig. 3a). In the presence of $\mathrm{Fe}(\mathrm{II})$ chloride, the mean root length remained constant for all REE concentrations, however it showed a statistically significant decrease with respect to control condition in the absence of $\mathrm{Fe}(\mathrm{II})$. (Fig. 1). No significant difference in the rice root biomass was observed, with $\mathrm{Fe}(\mathrm{II})$ chloride, when comparing the results of control (no REE added) and low REE concentration (0.5 mg/L) experiments (Fig. 2). For the $1 \mathrm{mg} / \mathrm{L}$ REE condition, however, a significant increase in root biomass was recorded, suggesting that the addition of chloride enhanced root growth (Fig. 2). This result is consistent with those of previous studies, which reported beneficial effects of the application of chloride on root development (Kimura et al., 2004; Chen et al., 2016; Jia et al., 2017). In addition, this result is in good agreement with previous works, which suggest that chloride $\left(\mathrm{Cl}^{-}\right)$stimulates root growth through two different mechanisms: (1) an osmoregulatory role of $\mathrm{Cl}^{-}$in the plant, and (2) the indirect effect of $\mathrm{Cl}^{-}$ 
through control of the water potential, which may influence the root length of rice plants (Kimura et al., 2004; Chen et al., 2016; Jia et al., 2017).

A further interpretation of the speciation results in Fig. 3a for rice plants exposed to REE and $100 \mu \mathrm{mol} / \mathrm{L} \mathrm{Fe(II)} \mathrm{chloride,} \mathrm{suggests} \mathrm{that} \mathrm{the} \mathrm{most} \mathrm{mobile} \mathrm{REE} \mathrm{(i.e.} \mathrm{the} \mathrm{LREE)}$ would be the cause of the mild, but nonetheless detrimental effects on rice root length or biomass observed in Fig. 1 and Fig. 2. The LREE remain, for the most part, mobile in the presence of $\mathrm{Fe}$ (II) chloride and HFO, and could be considered responsible for the negative effects on rice plant growth (Fig. 1 and Fig. 2), as in the presence of Fe(II) chloride, a marked portion of the MREE and the HREE was removed from solution by complexation to HFO (Fig. 3a). This implies that the LREE played a role in the negative effects observed on the root length and biomass, also recorded for experiments carried out in the absence of Fe(II) salts (Fig. 1 and Fig. 2).

Fig. $3 b$ shows the speciation of the REE in the presence of Fe (II) sulfate. For the LREE, $5 \%$ to $10 \%$ of these elements are bound to HFO, whereas $30 \%$ to $35 \%$ are present as "free" $\mathrm{Ln}^{3+}$ ions, and the remaining $55 \%$ to $60 \%$ occur as the dissolved $\mathrm{LnSO}_{4}{ }^{+}$species. Fig. 3b shows, that a significant portion of the MREE and HREE are complexed by sulfate to form the soluble $\mathrm{LnSO}_{4}{ }^{+}$species. As such, $40 \%$ to $45 \%$ of the MREE and $25 \%$ to $40 \% \mathrm{HREE}$ remain in solution and are therefore available for absorption by the rice root. At the highest REE concentration of $1 \mathrm{mg} / \mathrm{L}$, a renewed negative effect on rice root length and biomass is observed with Fe(II) sulfate (Fig. 1 and Fig. 2). The magnitudes of the decrease in these two parameters are in good agreement with those of experiments conducted in the absence of Fe (II) salts (Fig. 1 and Fig. 2). The increase in MREE and HREE dissolved species 
concentration with sulfate are also indicated by the lower fractions of MREE and HREE bound to HFO, as compared to the Fe (II) chloride condition (Fig. 3a and Fig. 3b).

Upon addition of $\mathrm{Fe}$ (II) sulfate, a decrease in root length and biomass was recorded for REE concentrations of $1 \mathrm{mg} / \mathrm{L}$. At a $\mathrm{pH}$ of 5.7 , the $\mathrm{pH}$ of the rice growth medium, $\mathrm{LnSO}_{4}{ }^{+}$should be present as the main form of the REE interacting with the rice root. This is consistent with the results of $\mathrm{Zhu}$ et al. (2016), who showed that $\mathrm{LnSO}_{4}{ }^{+}$is the dominant species within the $\mathrm{pH}$ range of 3.4 and 6.0 under similar solution conditions. The results of speciation calculations in Fig. 3b, indicate that $\mathrm{SO}_{4}{ }^{2-}$ more strongly complexes the MREE and HREE $\left(\log _{10} K_{\text {average }}=3.16 \pm 0.24 ;\right.$ Schijf and Byrne, 2004) rather than the LREE $\left(\log _{10}\right.$ $\mathrm{K}_{\text {average }}=2.14 \pm 0.32$; Schijf and Byrne, 2004). The stronger association of the MREE and HREE with $\mathrm{SO}_{4}{ }^{2-}$ would lead to a partial remobilization of MREE and HREE as soluble $\mathrm{LnSO}_{4}{ }^{+}$species. The fractions of the REE bound to HFO upon the initial addition of $\mathrm{Fe}$ (II) chloride decrease from ranges of 55 to $60 \%$ and 70 to $85 \%$ for MREE and HREE respectively, to 30 to $37 \%$ and 55 to $75 \%$ in the case of added Fe (II) sulfate (Fig. 3a and Fig. 3b). This suggests that the MREE and HREE, present in the form $\mathrm{LnSO}_{4}{ }^{+}$, would be available as dissolved species to be the cause of the regained decrease in shoot and root growth at the highest concentration of $1 \mathrm{mg} / \mathrm{L} \mathrm{REE} \mathrm{(Fig.} 1$ and Fig. 2). This negative effect may be induced by the requirement of the rice plant to maintain a cation/anion balance (Marschner, 2011).

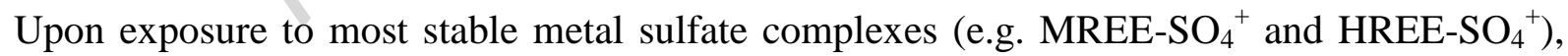
the rice plant root can uptake $\mathrm{SO}_{4}{ }^{2-}$ for plant nutrition and metabolism, inducing simultaneous cation (e.g. MREE and HREE) absorption to maintain osmotic balance (McLaughlin et al., 1998). This mechanism would then constitute a plausible explanation for the regained toxic effects to the rice plant observed for highest REE concentrations in the presence of $\mathrm{Fe}$ (II) sulfate (Fig. 1 and Fig. 2). 
As mentioned earlier, the results in Fig. 1 and Fig. 2 involving Fe(II) chloride suggest that the LREE are toxic to rice plants, as well as the remobilization of the MREE and HREE in the presence of $\mathrm{Fe}(\mathrm{II})$ sulfate (Fig. 3b), which cause a detriment of plant growth at highest REE concentrations of $1 \mathrm{mg} / \mathrm{L}$ (Fig. 1 and Fig. 2). These mechanisms may serve to interpret the results of previous works involving field studies, which have shown that the REE patterns in plant roots are consistent with those of local soil particles, mainly composed of $\mathrm{Fe}$ oxyhydroxides and possibly clay minerals (Brioschi et al., 2013). These soil particles near roots (i.e. in the rhizospheric zone) are the main source of REE to plants. Their enhanced chemical weathering in the rhizosphere, for example by acid mine drainage, leads to soil acidification resulting in the solubilization of HREE from stable inorganic ligands (Mn- and Fe-oxides) which can then be taken up by plant roots (Hopkins and Hüner, 2009; Brioschi et al., 2013). This is consistent with the REE speciation modeling results in this study, which in the presence of $\mathrm{SO}_{4}{ }^{2-}$ suggest the formation of MREE-SO ${ }_{4}{ }^{+}$and $\mathrm{HREE}-\mathrm{SO}_{4}{ }^{+}$species, and a lower fraction of the REE sorbing to HFO (Fig. 3b). The presence of more soluble REE species with $\mathrm{SO}_{4}{ }^{2-}$ may explain the regained toxic effects on rice plant growth, through root absorption of REE sulfate complexes as suggested by McLaughlin et al. (1998) and by the results in Fig. 1 and Fig. 2.

\subsection{The role of $\mathrm{Fe}(\mathrm{III})$ oxyhydroxides on the $\mathrm{REE}$ effects on rice plant growth}

The oxidation of the Fe(II) in these experiments may play a key role in attenuating the effects of REE absorption and toxicity to the rice plant. The added Fe (II) would be readily oxidized to Fe (III) oxyhydroxide phases. Figure 4 shows the presence of Fe (III) oxyhydroxides (e.g. ferrihydrite), heterogeneously covering the rice root surface. These 
Fe(III) phases have been suggested to act as filters of trace elements (e.g. MREE and HREE) (Liu et al., 2005; Fu et al., 2011; Yamaguchi et al., 2014). Mechanisms such as surface complexation or co-precipitation in the presence of these Fe(III) minerals would be expected to prevent metal cations, such as "free" $\mathrm{Ln}^{3+}$, from being absorbed by rice plant roots (Liu et al., 2005; Fu et al., 2011; Yamaguchi et al., 2014). In this study, the formation of iron (III) minerals on the rice root was observed both in the presence of $\mathrm{Fe}(\mathrm{II})$ chloride or $\mathrm{Fe}(\mathrm{II})$ sulfate. Sorption of the REE to root iron (III) oxyhydroxides may be supported by $\log _{10}$ values of metal sorption constants $(K)$, of the form $K=\left[R E E-L^{(n-m)}\right] /\left[R_{E} E^{n+}\right]\left[L^{m-}\right]$ ), which show that for REE complexation to iron (III) oxyhydroxides, $\log _{10} \mathrm{~K}$ values increase as the ionic radii of the REE decreases. For example, La presents a $\log _{10} \mathrm{~K}$ of 1.68 , whereas Lu shows a value of 3.47 (Liu et al., 2017). This suggests that as the radii of the REE decreases the stronger the binding to HFO as shown in Fig. 3a and Fig. 3b. This result further implies a weaker binding of the LREE to HFO (Fig. 3a and 3b). The higher solubility of the LREE, together with the negative growth effects observed upon addition of Fe (II) chloride, confirm that the LREE are toxic to the rice plant.

Previous works have demonstrated that solution complexation of the REE with organic and inorganic ligands plays a significant role for the absorption of these elements by plant roots (Ding et al., 2006; Liang et al., 2008). In this study, speciation calculation results may serve to better understand the effects of $\mathrm{Cl}^{-}, \mathrm{SO}_{4}{ }^{2-}$ and, $\mathrm{Fe}$ (III) dissolved species or mineral precipitates on the complexation and partitioning of the REE and their interaction and absorption by the rice root. The oxidation of Fe (II) leads to the development of amorphous Fe(III) oxyhydroxides, such as the iron precipitates observed on the root surface in Fig. 4. Precursor $\mathrm{Fe}(\mathrm{III})$ aqueous species, such as $\mathrm{Fe}(\mathrm{OH})^{2+}$ or $\mathrm{Fe}(\mathrm{OH})_{2}{ }^{+}$show $\log _{10} \mathrm{~K}$ values of 11.3 and 21.8 respectively (Baes and Mesmer, 1981), whereas, Fe(III) sulfate species, including 
$\mathrm{Fe}\left(\mathrm{SO}_{4}\right)_{2}{ }^{-}$and $\mathrm{FeH}\left(\mathrm{SO}_{4}\right)_{2}{ }^{0}$ have corresponding $\log _{10} \mathrm{~K}$ values in the ranges of 5.4 to 7.6 and 8.1 to 10.0 (Langmuir, 1997; Casas et al., 2005). The magnitude of $\log _{10} \mathrm{~K}$ for hydroxide and sulfate complexation by $\mathrm{Fe}$ (III) aqueous species, suggests a competition between $\mathrm{SO}_{4}{ }^{2-}$ and $\mathrm{OH}^{-}$anions for $\mathrm{Fe}$ (III). This could imply that a lower fraction of the total Fe(III) initially added may be available for the formation of Fe (III) oxyhydroxides, leading to the diminished fractions of the MREE and HREE scavenged by HFO, as shown in Fig. $3 b$.

Figure 5 shows the concentration of REE in $\mathrm{mg} / \mathrm{kg}$ in shoot (Fig. $5 \mathrm{a}$ and $5 \mathrm{~b}$ ) or root (Fig. 5c and 5d) biomass for experiments in the presence of $0.5 \mathrm{mg} / \mathrm{L}$ and $1 \mathrm{mg} / \mathrm{L} \mathrm{REE}$, and with further addition of $100 \mu \mathrm{mol} / \mathrm{L} \mathrm{Fe}(\mathrm{II})$ sulfate or Fe(II) chloride, as mentioned previously. For all conditions in Fig. 5, a lower concentration of the REE can be observed in roots and shoots, in the presence of $\mathrm{Cl}^{-}$, compared to $\mathrm{SO}_{4}{ }^{2-}$. This result may complement the modeling results in Fig. 3 and support an enhanced absorption of $\mathrm{LnSO}_{4}{ }^{+}$species by the plant root, however this effect would have to be the subject of a subsequent study focusing on investigating $\mathrm{Ln}^{3+}$ speciation with iron (III) oxides on the rice root surface. The results shown in Fig. 5c and 5d for the quantification of REE in concentrations in roots, show a decrease in MREE and HREE concentrations, both in the presence of $\mathrm{Fe}(\mathrm{II})$ sulfate and $\mathrm{Fe}(\mathrm{II})$ chloride and at $0.5 \mathrm{mg} / \mathrm{L}$ and 1 $\mathrm{mg} / \mathrm{L}$ REE. This result suggests the presence of Fe (III) plaques on the rice root, as $\log _{10} \mathrm{~K}$ values propose a stronger binding of the MREE and HREE to hydrous ferric oxide strong sites (Liu et al. 2017). In addition, the "flat" patterns observed for the REE series in Fig. 5, and the absence of a Ce anomaly for all experimental conditions, could suggest a first step binding of the REE to organic matter, and subsequently to mineral phases such as hydrous ferric oxides as reported in previous studies (Davranche et al., 2004; 2015), however further quantification of the REE sorption and speciation mechanisms in the rice root rhizosphere are required to provide conclusive evidence. In addition, normalization of the patterns shown previously in Fig. 5 to the control experiments, further evidences a lower concentration of REE in roots and 
shoots, in the presence of $\mathrm{Cl}^{-}$, as with $\mathrm{SO}_{4}{ }^{2-}$ (Fig. 6). This better illustrates REE fractionation. Indeed, in the shoots, a LREE to MREE enrichment is observed, whereas MREE enriched patterns with a small Tetrad effect are observed for the roots. This latter results highlight the role of the iron oxides even if the slope of the REE patterns is smaller. These results suggest that plants may preferentially absorb the LREE. This can further indicate that they are able to discriminate between cations differing by diameter and charge. Calcium and LREE to MREE have almost identical ionic radii (Shannon, 1976), suggesting that LREE and HREE are therefore able to competitively replace $\mathrm{Ca}$ ions in biological systems.

As shown by Brioschi et al. (2013) the transfer of the REE in soil-plant systems thus has been proposed to be intimately coupled with the Fe cycle. Iron has been shown to be essential for plant growth, suggesting the development of strategies by plants destined to maximize Fe absorption (e.g., Robin et al. 2008). Iron/REE interaction in soils would imply that the same processes that may mobilize iron in the rhizosphere (e.g., exudation of siderophores; Kraemer et al., 2017; competition with bacteria; Martinez et al., 2014) may also target the REE (e.g., Wiche et al. 2016). Even if the mechanism of formation of these iron (III) minerals has not yet been fully quantified, iron plaques have been proposed to play a central role in the control of trace metal uptake by rice plants in combination with other competitors (i.e., siderophores, bacteria, simple organic acids, organic matter). REE patterns of iron plaques (Fig. 7a), are different relative to those typical of inorganic HFO (Fig. 7b). They show a decrease in the Ce anomaly and a preferential uptake of HREE relative to LREE. This can be interpreted as a competition of REE sorption with organic matter (humic materials or siderophores) that may reduce Ce anomaly, or as the enhanced sorption of the HREE by organic reactive solids, such as bacteria. Eventually, small organic acids (like oxalate and acetate, e.g. Fig. 7b) may play a complementary role and favor 
MREE>LREE>HREE extraction from solution (e.g., Josso et al., 2018). Overall, the absence of cerium anomalies in these experiments, suggests that $\mathrm{Ce}$ occurred as $\mathrm{Ce}$ (III) during the metabolic processes of the Nep cai hoa vang rice variety or that the organic complexes, which usually depress amplitudes of Ce anomaly, drive the REE speciation in plant fluids (Davranche et al., 2008).

The shoot and root REE patterns of control experiments shown in Fig. 5 display HREE enrichment with $\mathrm{La} / \mathrm{Sm}$ ratios ranging between 1.34 and 1.64 and $\mathrm{Gd} / \mathrm{Yb}$ ratios oscillating within values of 0.73 and 0.89 . At $0.5 \mathrm{mg} / \mathrm{L} \mathrm{REE}$ and $100 \mu \mathrm{mol} / \mathrm{L} \mathrm{Fe}$ (II) sulfate or $\mathrm{Fe}$ (II) chloride, shoot and root REE patterns become rather flat with a $\mathrm{La} / \mathrm{Sm}$ ratio between 1.17 and 1.39 and a $\mathrm{Gd} / \mathrm{Yb}$ ratio in the range of 1.05 to 1.17 . Eventually these patterns become LREE enriched when considering the $1 \mathrm{mg} / \mathrm{L}$ REE concentration in the presence of $100 \mu \mathrm{mol} / \mathrm{L} \mathrm{Fe}$ (II) sulfate or Fe (II) chloride with a La/Sm ratio between 1.23 and 1.47 and a $\mathrm{Gd} / \mathrm{Yb}$ ratio of 1.09 to 1.22 . These results can be interpreted to be a consequence of REEFeOx-OM interactions as previously shown by Davranche et al. (2004). At higher iron concentration, the HREE enrichment, which is consistent with an increasing REE mobility with increasing atomic number, is in favor of a speciation driven by solution complexation (i.e. by sulfate or free ionic species) as already highlighted for Vitis vinifera by Censi et al. (2014)

\subsection{Protective effects of iron plaques on rare earth element toxicity}

Rice plants adapt to waterlogged environments by releasing oxygen from their roots to produce an oxidizing medium in their rhizosphere and minimize the risk of toxic effects, especially of ferrous iron and other reduced elements (Chen et al., 1980). Under these conditions, insoluble ferric iron precipitates form on the root surface, and although this 
mechanism may be protective against toxic elements, it can also impede to a significant degree the uptake of essential nutrients (Chen et al, 1980; Fu et al., 2011). Both the generation of an oxidizing environment and the coating of the root surface by iron (III) mineral plaques control the speciation and partitioning of the REE in the rhizosphere of rice and in consequence, the uptake of these elements by the plant roots. The generation of iron (III) oxyhydroxide precipitates on the root surface, coupled to the oxidizing soil conditions near the rice roots developed, in part, from the release of $\mathrm{O}_{2}$ from the root surface (Liu et al., 2005; Fu et al., 2011; Yamaguchi et al., 2014) would then constitute a mechanism of defense against REE absorption by the rice plant. However, the effects of iron (III) oxyhydroxides on REE mobility in soils may be influenced by the presence of other reactive solids such as rhizospheric bacteria. The REE have been shown to sorb to bacteria cell surfaces which could also affect REE mobility. The $\log _{10}$ of REE sorption constants in the presence of Bacillus subtilis ranged from $1.08 \pm 0.04$ to $1.40 \pm 0.04$ for the light REE (LREE: La to Eu), and from $1.36 \pm 0.03$ to $2.18 \pm 0.14$ for the heavy REE (HREE: Gd to Lu) at biomass concentrations of $1.3 \mathrm{~g} / \mathrm{L}$ (Martinez et al., 2014). Furthermore, as indicated by the experiments in this study, the presence of $\mathrm{Cl}^{-}$and $\mathrm{SO}_{4}{ }^{2-}$ influence the extent of REE sorption to $\mathrm{HFO}$, and may play a significant role in the form and concentration of the REE species taken up by the plant root heterogeneously covered by iron (III) precipitates.

\subsection{The role of organic and inorganic ligands on REE speciation}

As suggested by the results of hydroponic studies in the present study, the REE negatively affect rice plant growth. As shown herein, the presence of inorganic ligands (i.e. $\mathrm{SO}_{4}{ }^{2-}$ and $\mathrm{Cl}^{-}$), and iron (III) oxyhydroxide phases associated with the rice root played a key role in controlling the toxic effects of the REE. In the natural environment, however, the toxic 
effects of these and other trace elements are dependent on their form in the aquatic soil solution, which is composed of a significant number of competing inorganic and organic ligands able to complex the REE (Tang and Johannesson, 2003; Johannesson et al., 2004; Davranche et al., 2015; Liu et al., 2017). The REE have been shown to interact with iron and manganese oxide surfaces, as well as to complex inorganic ligands. These elements are suggested to partition and fractionate in the presence of oxide reactive solids and clay minerals (Tyler, 2004; Liu et al., 2017), natural organic matter and mineral organic matter composites (Johannesson et al., 2004; Davranche et al., 2015). As indicated previously by Liu et al. (2017) and references therein, further control on the speciation of these elements in natural aquatic environments is exerted by inorganic ligand (e.g. $\mathrm{OH}^{-}, \mathrm{HCO}_{3}{ }^{-}, \mathrm{CO}_{3}{ }^{2-}, \mathrm{NO}_{3}{ }^{-}, \mathrm{Cl}^{-}$ , $\mathrm{PO}_{4}{ }^{3-}$ ) complexation as well as, by the interaction of the REE with soil bacteria species (Martinez et al., 2014). Due to the complex nature of REE speciation in soils, an exhaustive quantification and understanding of the toxic effects of these elements, as "free" cations (i.e. $\mathrm{Ln}^{3+}$ ) and their forms, to plants in contaminated soils, must result from the interpretation of complementary simpler hydroponic laboratory based experiments and future studies of the REE behavior in natural soils.

\section{Conclusion}

In this study, a significant decrease in rice plant growth was observed upon addition of increasing concentrations of REE, of $0.5 \mathrm{mg} / \mathrm{L}$ and $1 \mathrm{mg} / \mathrm{L}$. Rice plants were exposed to all REE, and also to the presence of Fe(II) chloride or Fe(II) sulfate. During the experiments, iron (III) oxide mineral deposits or iron plaques were developed on the rice plant root surface. In the presence of iron (II) chloride, changes in plant growth were observed within the error in biomass or measured length of shoots and roots. For the case of iron (II) sulfate addition, a 
toxic effect was recorded for the highest REE concentration of $1 \mathrm{mg} / \mathrm{L}$. As a first account of this observation, speciation modeling showed that with iron (II) chloride, the REE were complexed for the most part to hydrous ferric oxides. These results showed that the LREE remained soluble as free ions with iron (II) chloride, whereas a large fraction of the MREE and the HREE were bound to the iron (III) oxides. Mild toxic effects were recorded from the REE for the iron (II) chloride experiments, suggesting that the LREE part take in exerting negative growth effects to the rice plant. These detrimental consequences for the rice plant are further indicated by the results from the speciation modeling in the presence of iron (II) sulfate, which showed that a significant portion of the MREE and HREE (previously bound to iron (III) oxide phase with iron (II) chloride) were present as soluble $\mathrm{LnSO}_{4}{ }^{+}$species. This coincided with the regained negative effects on rice plant growth at $1 \mathrm{mg} / \mathrm{L} \mathrm{REE}$ for these experiments. Therefore, this indicates a renewed decrease in growth in the presence of the dissolved and available $\mathrm{LnSO}_{4}{ }^{+}$species. The effects of REE on plant growth are diverse, however their interaction with iron (III) reactive solids is one of the key mechanisms leading to the determination of the REE forms fractionated and enriched in plant parts, including roots and aerial plant portions. The presence of iron (II) sulfate or chloride and their effects on REE speciation reveal a complex system of reactions around the formation of iron (III) oxides on the root surface. Further studies are needed, however, to quantify the modes in which REE species interact with the surface of these iron (III) oxide. These further studies will allow obtaining precise results for REE binding constants, sorption mechanisms and sorption kinetics, able to form part of surface complexation and kinetic models, needed to predict the fate of the REE in the plant rhizosphere. The results in this study from laboratory hydroponic experiments will further serve to constrain the speciation modeling of the REE in complex natural systems, therefore contributing to the quantification of the forms of the REE and their interactions with reactive solids in the natural environment. 


\section{Acknowledgments}

Funding for this project was provided by the Institute of Earth and Environmental Science, the Faculty of Environment and Natural Resources of the University of Freiburg to REM and UniLaSalle Beauvais to OP and MPF. The authors would like to thank Sigrid HirthWalther and Nataliya Paunova of the Earth and Environmental Science Institute at the University of Freiburg for sample preparation and analyses. Furthermore, the authors acknowledge Dr. Qiuju Yu of the Biology Department at the University of Freiburg for advice on optimal rice plant growth conditions, and Dr. Ralf Thomann of the Freiburger Material Forschungszentrum (FMF) at the University of Freiburg for SEM imaging. In addition, the authors would like to thank Dr. Petru Jitaru of UniLaSalle, Beauvais, for his help during analytical procedures. The authors would further like to thank the comments from the reviewers of this manuscript which helped improve the quality of this work.

\section{References}

Avula, B., Wang, Y-H., Smillie, T.J., Duzgoren-Aydin, N.S., Khan, I.A., 2010. Quantitative Determination of Multiple Elements in Botanicals and Dietary Supplements Using ICP-MS. J. Agr. Food Chem. 58, 8887-8894.

Baes, C.F., Mesmer, R.E., 1981. The Thermodynamics of Cation Hydrolysis. Am. J. Sci. 281 (7), 935-962.

Brioschi, L., Steinmann, M., Lucot, E., Pierret, M., Stille, P., Prunier, J., Badot, P., 2013. Transfer of rare earth elements (REE) from natural soil to plant systems: implications for the environmental availability of anthropogenic REE. Plant Soil 366, 143-163.

d'Aquino, L., Morgana, M., Carboni, M.A., Staiano, M., Antisari, M.V., Re, M., Lorito, M., Vinale, F., Abadi, K.M., Woo, S.L., 2009. Effect of some rare earth elements on the growth and lanthanide accumulation in different Trichoderma strains. Soil Biol. Biochem. 41 (12), 2406-2413. 
da Silva, Y.J.A.B., do Nascimento, C.W.A., Biondi, C.M., van Straaten, P., de Souza, V.S., da Silva, Y.J.A.B., dos Santos, C.A., de Araujo, J.D.T., 2017. Influence of metaluminous granite mineralogy on the rare earth element geochemistry of rocks and soils along a climosequence in Brazil. Geoderma 306, 28-39.

Bashan, Y., de-Bashan, L.E., 2005. Fresh-weight measurements of roots provide inaccurate estimates of the effects of plant growth-promoting bacteria on root growth: a critical examination. Soil Biol Biochem 37, 1795-1804.

Batty, L.C., Baker, A.J.M., Wheeler, B.D., 2002. Aluminium and phosphate uptake by Phragmites australis: The role of Fe, Mn and Al root plaques. Ann. Bot. 89, 443-449.

Berner, E.K., Berner, R.A., Moulton, K.L., 2003. Plants and mineral weathering: present and past, in: Drever JI, Turekian KK (Eds.), Surface and ground water, weathering and soils. Elsevier, pp 169-188.

Brookins, D.G., 1989. Aqueous Geochemistry of Rare Earth Elements, in: Lipin, B.R., McKay, G.A. (Eds.), Geochemistry and Mineralogy of Rare Earth Elements. Reviews in Mineralogy, vol. 21, Mineralogical Society of America, Washington, D.C., pp 201-223.

Casas, J.M., Crisótomo, G., Cienfuentes, L., 2005. Speciation of the $\mathrm{Fe}(\mathrm{II})-\mathrm{Fe}(\mathrm{III})-\mathrm{H}_{2} \mathrm{SO}_{4^{-}}$ $\mathrm{H}_{2} \mathrm{O}$ system at 25 and 50 degrees C. Hydrometallurgy 80 (4), 254-264.

Censi, P., Saiano, F., Pisciotta, A., Tuzzolino, N., 2014. Geochemical behaviour of rare earths in Vitis vinifera grafted onto different rootstocks and growing on several soils. Sci. Total Environ. 473-474, 597-608.

Chen, Z.C., Yamaji, N., Fujii-Kashino, M., Ma, J.F., 2016. A Cation-Chloride Cotransporter Gene Is Required for Cell Elongation and Osmoregulation in Rice. Plant Physiol. 171, 494507.

Chen, C.C., Dixon, J.B., Turner, F.T., 1980. Iron coatings on rice roots - mineralogy and quantity influencing factors. Soil Sci. Soc. Am. J. 44 (3), 635-639.

Davranche, M., Gruau, G., Dia, A., Le Coz-Bouhnik, M., Marsac, R., Pédrot, M., Pourret, O., 2017. Chapter 7. Rare Earth Elements in Wetlands, in: Trace Elements in Waterlogged Soils and Sediments. Rinklebe J., Knox A.S., Paller M. (Eds.), Taylor \& Francis Group/CRC Press, pp 135-162.

Davranche, M., Gruau, G., Dia, A., Marsac, R., Pédrot, M. and Pourret, O., 2015. Biogeochemical Factors Affecting Rare Earth Element Distribution in Shallow Wetland Groundwater. Aquat. Geochem. 21, 197-215. 
Davranche, M., Grybos, M., Gruau, G., Pédrot, M., Dia, A., Marsac, R., 2011. Rare earth element patterns: A tool for identifying trace metal sources during wetland soil reduction. Chem. Geol. 284, 127-137.

Davranche, M., Pourret, O., Gruau, G., Dia, A., Jin, D., Gaertner, D., 2008. Competitive binding

of REE to humic acid and manganese oxide: Impact of reaction kinetics on development of cerium anomaly and REE adsorption. Chem. Geol. 247, 154-170.

Davranche, M., Pourret, O., Gruau, G. and Dia, A., 2004. Impact of humate complexation on the adsorption of REE onto Fe oxyhydroxide. J. Colloid Interface Sci. 277, 271-279.

Dia, A., Gruau, G., Olivié-Lauquet, G., Riou, C., Molénat, J., Curmi, P., 2000. The distribution of rare-earths in groundwater: Assessing the role of source-rock composition, redox changes and colloidal particles. Geochim. Cosmochim. Acta 64, 4131-4151.

Ding, S.M., Liang, T., Zhang, C.S., Wang, L.J., Sun, Q., 2006. Accumulation and fractionation

of rare earth elements in a soil-wheat system. Pedosphere 16, 82-90.

Fu, Y.-q., Liang, J.-p., Yu, Z.-w., Wu, D.-m., Cai, K.-Z., Shen, H., 2011. Effect of different iron forms on iron plaque on root surface and iron uptake in rice seedlings. Journal of Plant Nutrition and Fertilizer 17, 1050-1057.

Gaillardet, J., Millot, R., Dupre, B., 2003. Chemical denudation rates of the western Canadian orogenic belt: the Stikine terrane. Chem. Geol. 201 (3-4) 257-279.

Gardea-Torresdey, J.L., Peralta-Videa, J.R., Montes, M., de la Rosa, G., Corral-Diaz, B., 2004.

Bioaccumulation of cadmium, chromium and copper by Convolvulus arvensis L.: impact on plant growth and uptake of nutritional elements. Bioresource Technol. 92, 229-235.

Guthrie, J.W., Mandal, R., Salam, M.S.A., Hassan, N.M., Murimboh, J., Chakrabarti, C.L., Back, M.H., Gregoire, D.C., 2003. Kinetic studies of nickel speciation in model solutions of a well-characterized humic acid using the competing ligand exchange method. Anal. Chim. Acta 430 (1) 157-169.

Hansel, C.M., La Force, M.J., Fendorf, S., Sutton, S., 2002. Spatial and temporal association of As and Fe species on aquatic plant roots. Environ. Sci. Technol. 36, 1988-1994.

Hansel, C.M., Fendorf, S., Sutton, S., Newville, M., 2001. Characterization of Fe plaque and associated metals on the roots of mine-waste impacted aquatic plants. Environ. Sci. Technol. 35, 3863-3868. 
Himmelbauer, M.L., Loiskandl, W., Kastanek, F., 2004. Estimating length, average diameter and surface area of roots using two different Image analyses systems. Plant Soil 260 (1-2), 111-120.

Hoai, N.T.T., Shim, I.S., Kobayashi, K., Usui, K., Plant Growth Regul. 2003, 41, 159-164.

Hopkins, W.G., Hüner, N.P.A., 2009. Introduction to plant physiology. Wiley.

Hu, X., Ding, Z., Chen, Y., Wang, X., Dai, L., 2002. Bioaccumulation of lanthanum and cerium and their effects on the growth of wheat (Triticum aestivum L.) seedlings. Chemosphere 48, 621-629.

Hummel, W., Berner, U., Curti, E., Pearson, F. J., Thoenen, T. 2002. Nagra/PSI chemical thermodynamic database 01/01. Universal Publishers, Parkland, Florida.

Ichihashi, H., Morita, H., Tatsukawa, R., 1992. Rare earth element (REEs) in naturally grown plants in relation to their variation in soils. Environ. Pollut. 76, 157-162.

Jia, Y., Zou, D., Wang, J., Sha, H., Liu, H., Inayat, M.A., Sun, J., Zheng, H., Xia, N., Zhao, H., 2017. Effects of $\gamma$-Aminobutyric Acid, Glutamic Acid, and Calcium Chloride on Rice (Oryza sativa L.) Under Cold Stress During the Early Vegetative Stage. J. Plant Growth Regul. 36, 240-253.

Johannesson, K.H., Tang J., Daniels, J.M., Bounds, W.J., Burdige, D.J., 2004. Rare earth element concentrations and speciation in organic-rich blackwaters of the Great Dismal Swamp, Virginia, USA. Chem. Geol. 209, 271-294.

Josso, P., Roberts, S., Teagle, D.A.H., Pourret, O., Herrington, R., Ponce de Leon Albarran, C., 2018. Extraction and separation of rare earth elements from hydrothermal metalliferous sediments. Minerals Engineering 118, 106-121.

Kimura, K., Okumura, M., Yamasaki, S-i., 2004. Effects of chloride and sulfate application on root growth of rice. Soil Sci. Plant Nutr. 50 (3), 395-402.

Kraemer, D., Tepe, N., Pourret, O., Bau, M., 2017. Negative cerium anomalies in manganese (hydr)oxide precipitates due to cerium oxidation in the presence of dissolved siderophores. Geochim Cosmochim Acta 196, 197-208.

Liang, T., Ding, S., Song, W., Chong, Z., Zhang, C., Li, H., 2008. A review of fractionations of rare earth elements in plants. J. Rare Earth. 26, 7-15.

Langmuir, D., 1997. Aqueous Environmental Geochemistry. Prentice Hall. 
Liu, H., Pourret, O., Guo, H., Bonhoure, J., 2017. Rare earth elements sorption to iron oxyhydroxide: Model development and application to groundwater. Appl. Geochem. 87, 158166.

Liu, W.J., Zhu, Y.G., Smith, F.A., 2005. Effects of iron and manganese plaques on arsenic uptake by rice seedlings (Oryza sativa L.) grown in solution culture supplied with arsenate and arsenite. Plant Soil 277, 127-138.

Luo, Y-R., Bryne, R.H., 2001. Yttrium and rare earth element complexation by chloride ions at $25^{\circ}$ C. J. Solution Chem. $30,837-845$.

McLaughlin, M.J., Andrew, S.J., Smart, M.K., Smolders, E., 1998. Effects of sulfate on cadmium uptake by Swiss chard: I. Effects of complexation and calcium competition in nutrient solutions. Plant and Soil 202 (2), 211-216.

Marschner, H., 2011. Marschner's Mineral Nutrition of Higher Plants. Academic Press.

Martinez, R.E., Pourret, O., Takahashi, Y., 2014. Modeling of rare earth element sorption to the Gram positive Bacillus subtilis bacteria surface. J Colloid Interf Sci 413, 106-111.

Martinez, R.E., Marquez, J.E., Hoàng, T.B.H., Gieré, R., 2013. Open pit coal mining effects on rice paddy soil composition and metal bioavailability to Oryza sativa L. plants in Cam Pha, northeastern Vietnam. Environ. Sci. Pollut. Res. 20, 7686-7698.

Møller, C.L., Sand-Jensen, K., 2008. Iron plaques improve the oxygen supply to root meristems of the freshwater plant, Lobelia dortmanna. New Phytologist 179, 848-856.

Muehe, E.M., Eisele, J.F., Daus, B., Kappler, A., Harter, K., Chaban, C., 2014. Are rice (Oryza sativa L.) phosphate transporters regulated similarly by phosphate and arsenate? A comprehensive study. Plant Mol Biol 85, 301-316.

Ning, J.B., Xiao, S.L., 1989. Effects of rare earth elements application on day lily. Chinese Rare Earth. 10 (5), 52-54.

Pagano, G., Guida, M., Tommasi, F., Oral, R., 2015. Heath effects and toxicity mechanisms of rare earth elements - Knowledge gaps and research prospects. Ecotox. Environ. Safe. 115, 40-48.

Parkhurst, D. L., Appelo, C. A. J., 2013. Description of input and examples for PHREEQC version 3-a computer program for speciation, batch-reaction, one-dimensional transport, and inverse geochemical calculations. US geological survey techniques and methods, book, 6, 497 
Pang, X., Li, D., Peng, A., 2002. Application of rare-earth elements in the agriculture of China and its environmental behavior in soil. Environ Sci Pollut Res. 9, 143-148.

Pédrot, M., Dia, A., Davranche, M., Gruau, G., 2015. How do upper soil horizons control rare earth element patterns in shallow groundwaters? Geoderma 239-240, 84-96.

Pourret, O., Davranche, M., Gruau, G., Dia, A., 2007. Rare Earth Elements complexation with humic acid. Chem. Geol. 243, 128-141.

Reichman, S., Parker, D., 2005. Metal complexation by phytosiderophores in the rhizosphere in: Huang P, Gobran G (Eds.), Biogeochemistry of trace elements in the rhizosphere. Elsevier, Amsterdam, pp 129-156.

Robin, A., Vansuyt, G., Hinsinger, P., Meyer, J., Briat, J., Lemanceau, P., 2008. Iron dynamics in the rhizosphere: consequences for plant health and nutrition, in: Advances in agronomy. Academic Press, pp 183-225.

Sahrawat, K.L., 2005. Iron toxicity in wetland rice and the role of other nutrients. Journal of Plant Nutrition 27, 1471-1504.

Schijf, J., Byrne, R.H., 2004. Determination of $\mathrm{SO}_{4} \beta 1$ for yttrium and the rare earth elements at $\mathrm{I}=0.66 \mathrm{~m}$ and $\mathrm{t}=25^{\circ} \mathrm{C}$-implications for YREE solution speciation in sulfate-rich waters. Geochim. Cosmochim Acta, 68 (13), 2825-2837.

Sholkovitz, E.R., 1995. The aquatic chemistry of rare earth elements in rivers and estuaries. Aq. Geochem. 1, 1-34.

Tagami, K., Uchida, S., 2006. Transfer of REEs from nutrient solution to radish through fine roots and distribution in the plant. Journal of Alloy Compd. 408-412, 409-412.

Tang, J., Johannesson, K.H., 2003. Speciation of rare earth elements in natural terrestrial waters: Assessing the role of dissolved organic matter from the modeling approach. Geochim. Cosmochim. Acta 67, 2321-2339.

Tao, F., Hayashi, Y., Zhang, Z., Sakamoto, T., Yokozawa, M., 2008. Global warming, rice production and water use in China: Developing a probabilistic assessment. Agric. For. Meteor., 148, 94-110.

Thomas, P.J., Carpenter, D., Boutin, C., Allison, J.E., 2014. Rare earth elements (REEs): Effects on germination and growth of selected crop and native plant species. Chemosphere 96, $57-66$.

Wang, L.J., 2005. Accumulation and fractionation of rare earth elements in soil-rice systems. J. Rare Earth 23 (6), 747-751. 
Wiche, O., Kummer, N-A., Heilmeier, H., 2016. Interspecific root interactions between white lupin and barley enhance the uptake of rare earth elements (REEs) and nutrients in shoots of barley. Plant Soil 402, 235-245.

Wiche, O., Heilmeier, H., 2016. Germanium (Ge) and rare earth element (REE) accumulation in selected energy crops cultivated on two different soils. Miner. Eng. 92, 208-215.

Yamaguchi, N., Ohkura, T., Takahashi, Y., Maejima, Y., Arao, T., 2014. Arsenic distribution and speciation near rice roots influenced by iron plaques and redox conditions of the soil matrix. Environ. Sci. Technol. 48, 1549-1556.

Yoshida, S., Forno, D.A., Cook, J.H., Gomez, K.A., 1976. Laboratory Manual for Physiological Studies of Rice, International Rice Research Institute, pp. 61-65.

Zhu, Z., Liu, C-Q., Wang, Z-L., Jun Li, X.L., 2016. Rare earth elements concentrations and speciation in rainwater from Guiyang, an acid rain impacted zone of Southwest China. Chem. Geol. 442, 23-34.

Zhuang, M., Wang, L., Wu, G., Wang, K., Jiang, X., Liu, T., Xiao, P., Yu, L., Jiang, Y., Song, J., Zhang, J., Zhou, J., Zhao, J., Chu, Z., 2017. Health risk assessment of rare earth elements in cereals from mining area in Shandong, China. Nature 7 (9772), 1-5. 


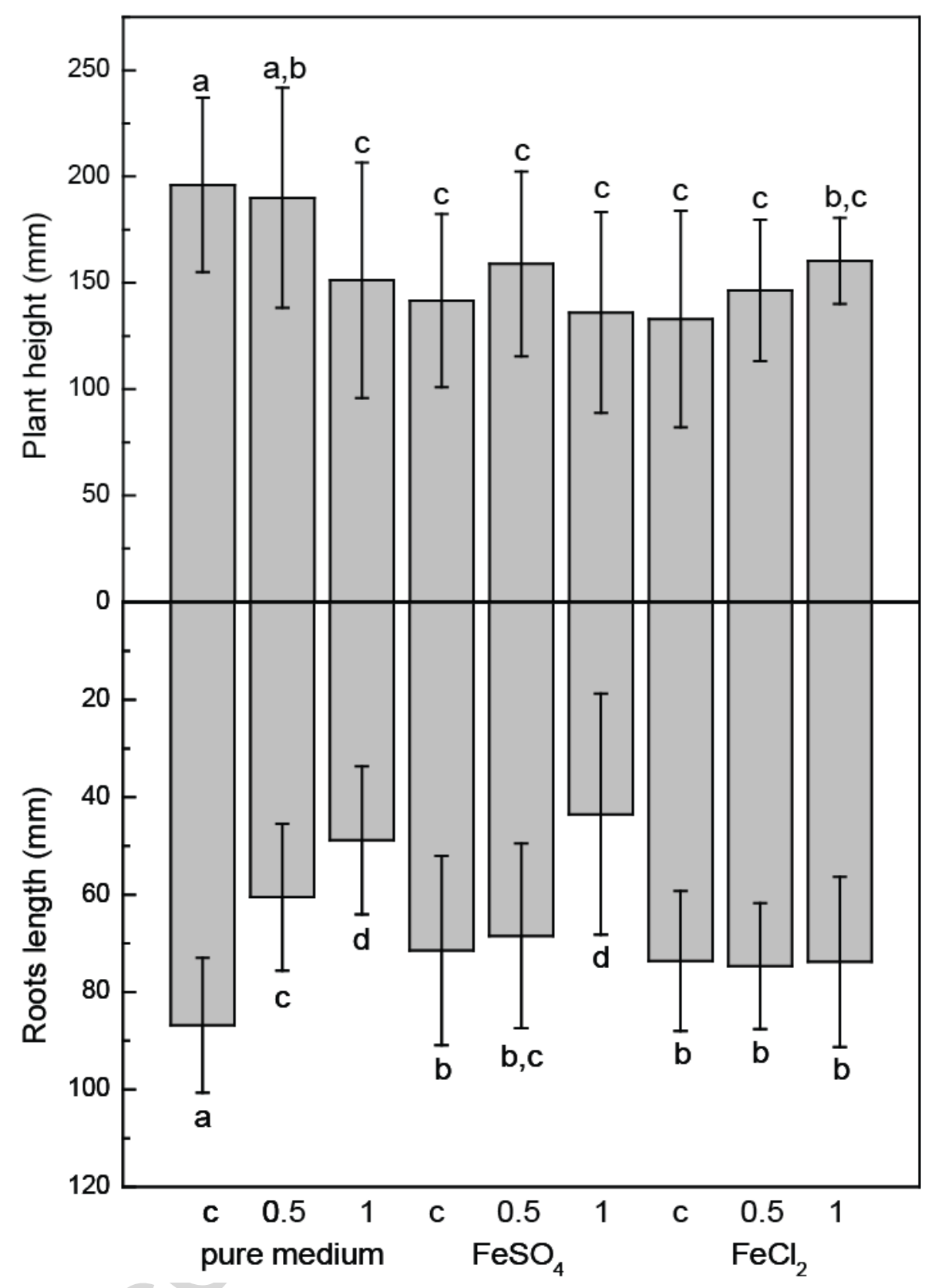

Fig. 1 Bar graphs showing the effects of REE on rice shoot and root length. The labels: "pure medium", "FeSO 4 " and " $\mathrm{FeCl}_{2}$ " correspond to experiments conducted in the presence of REE at $0.5 \mathrm{mg} / \mathrm{L}$ and $1 \mathrm{mg} / \mathrm{L}, \mathrm{REE}+100 \mu \mathrm{mol} / \mathrm{L} \mathrm{Fe}$ (II) sulfate, and REE + $100 \mu \mathrm{mol} / \mathrm{L} \mathrm{Fe}$ (II) chloride respectively. For each of these conditions, labels: "c", " 0.5 " and " 1 " correspond to REE concentrations of $0 \mathrm{mg} / \mathrm{L}$ (control), $0.5 \mathrm{mg} / \mathrm{L}$ and $1 \mathrm{mg} / \mathrm{L}$ respectively. Error bars correspond to the standard deviation of measurements as indicated in the text. There is no statistically significant difference in length between conditions when the same letter is shown. 


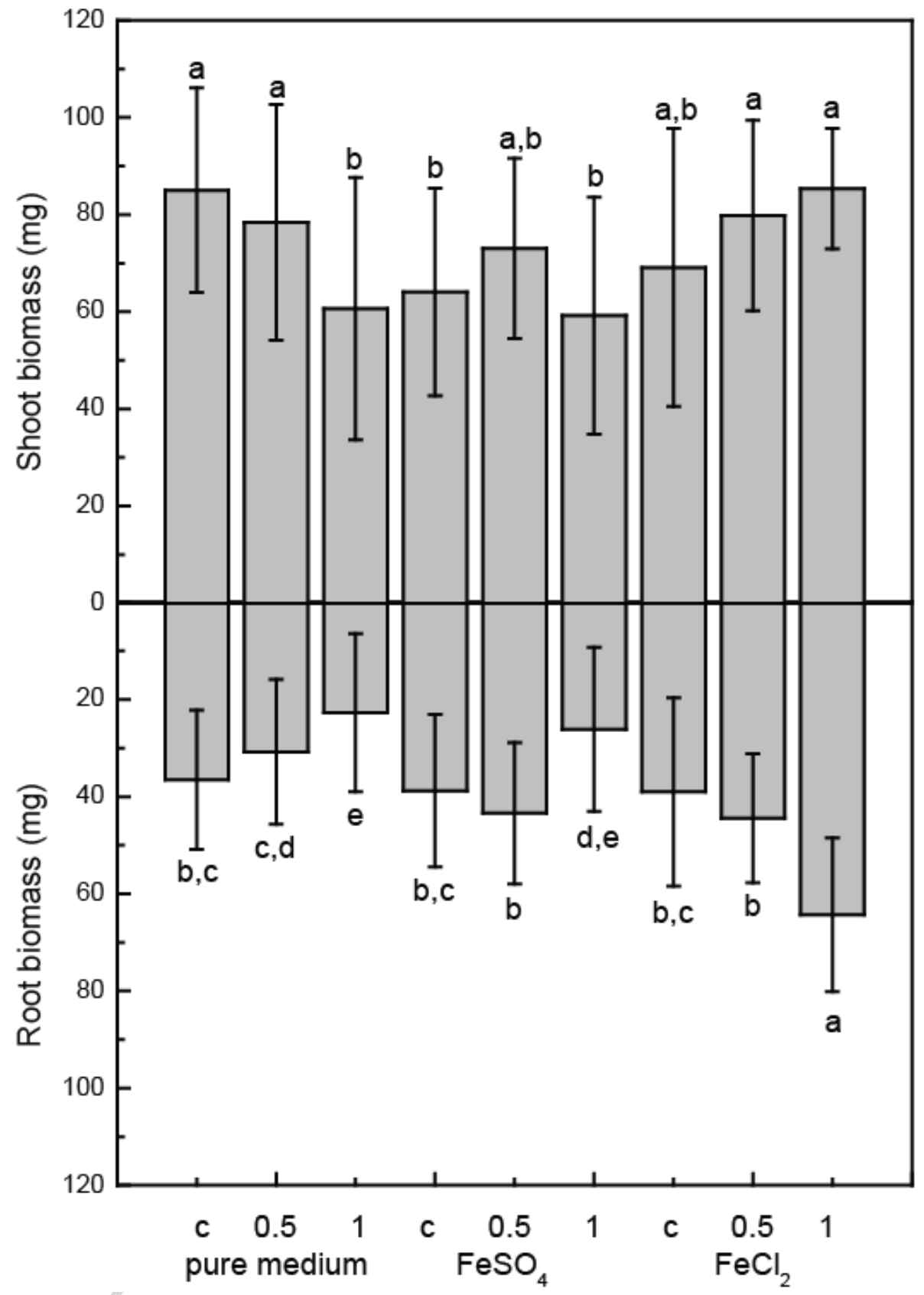

Fig. 2 Bar graphs showing the effects of REE on rice shoot and root biomass. The labels: "pure medium", "FeSO 4 " and " $\mathrm{FeCl}_{2}$ " correspond to experiments conducted in the presence of REE at $0.5 \mathrm{mg} / \mathrm{L}$ and $1 \mathrm{mg} / \mathrm{L}, \mathrm{REE}+100 \mu \mathrm{mol} / \mathrm{L} \mathrm{Fe}$ (II) sulfate, and REE + $100 \mu \mathrm{mol} / \mathrm{L} \mathrm{Fe}$ (II) chloride respectively. For each of these conditions, labels: "c", " 0.5 " and " 1 " correspond to REE concentrations of $0 \mathrm{mg} / \mathrm{L}$ (control), $0.5 \mathrm{mg} / \mathrm{L}$ and $1 \mathrm{mg} / \mathrm{L}$ respectively. Error bars correspond to the standard deviation of measurements as indicated in the text. There is no statistically significant difference in biomass between conditions when the same letter is shown. 
a

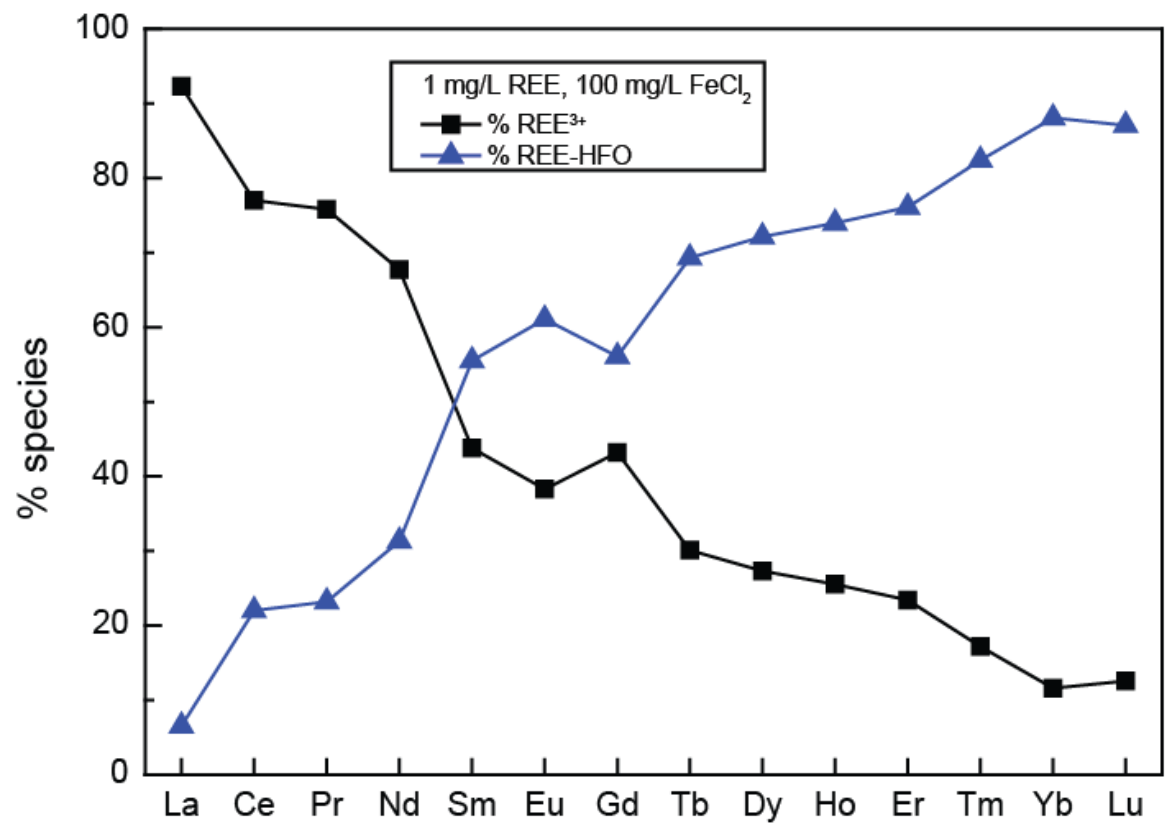

$\mathrm{b}$

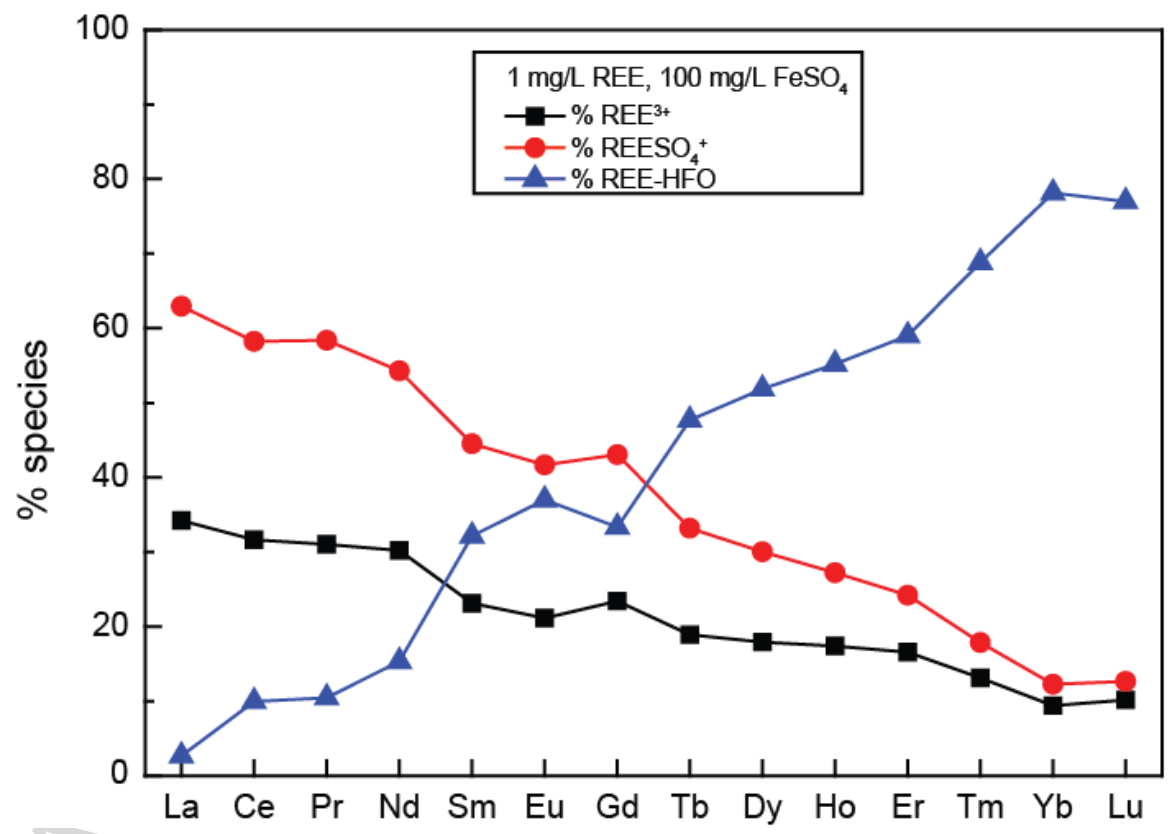

Fig. 3 Results of PHREEQC modeling of REE speciation for the conditions in this study, (a) in the presence of $\mathrm{Fe}$ (II) chloride and (b) with Fe(II) sulfate, for $1 \mathrm{mg} / \mathrm{L} \mathrm{REE}$ and $100 \mu \mathrm{mol} / \mathrm{L}$ $\mathrm{Fe}$ (II) salt. The black square, blue triangle and red circle markers, correspond to the fraction of REE as "free" cations (i.e. $\mathrm{Ln}^{3+}$ or $\mathrm{REE}^{3+}$ ), REE iron (III) oxyhydroxide complexes, and REE sulfate complexes, respectively. 


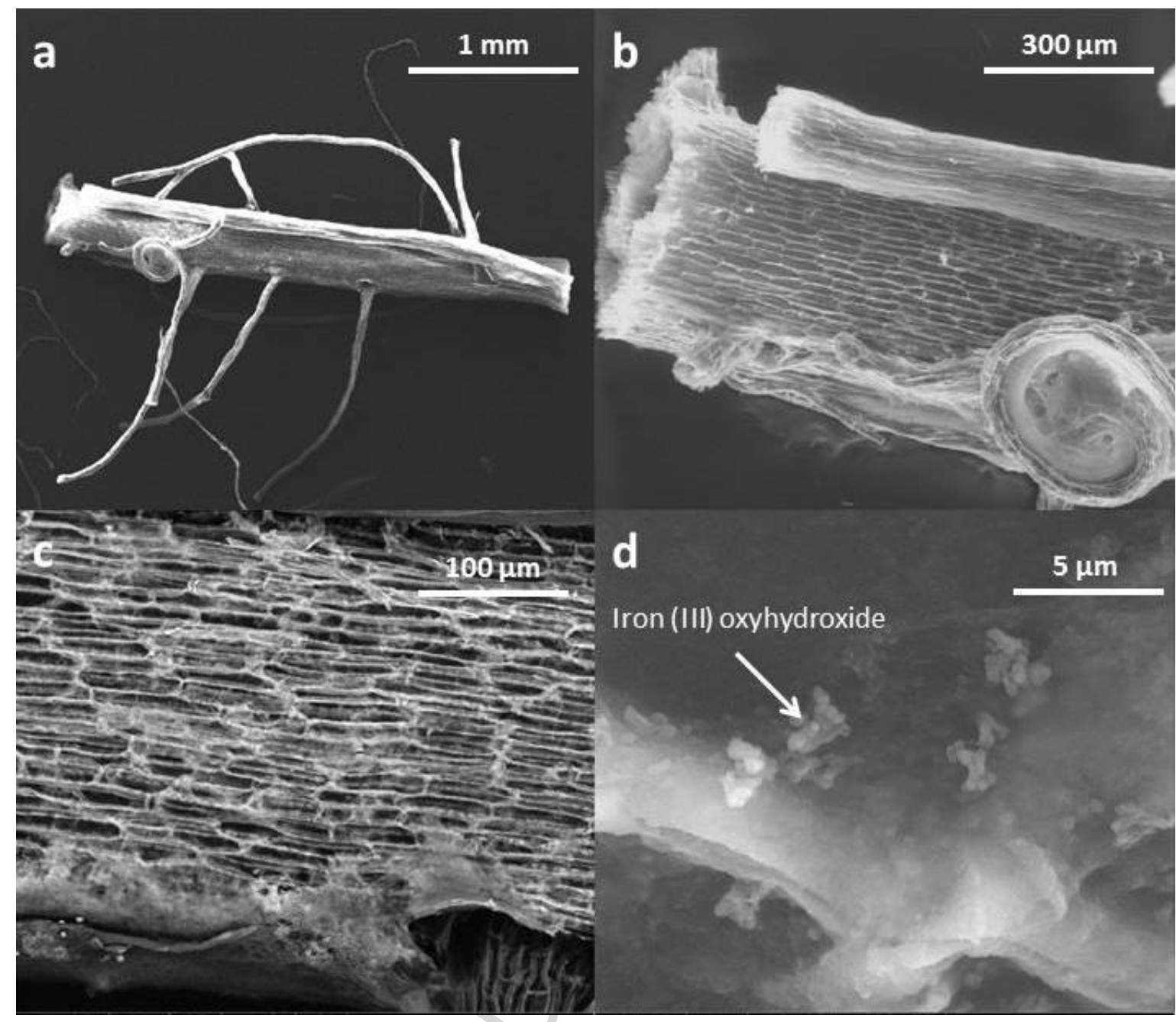

Fig. 4. SEM images of the rice root surface after 14 days of exposure to the $100 \mu \mathrm{mol} / \mathrm{L}$ concentration of Fe (II) sulfate or Fe (II) chloride. (a), (b), (c) and (d) show the iron (III) oxyhydroxide solid phases present on the rice root surface, at increasing resolution. 
a

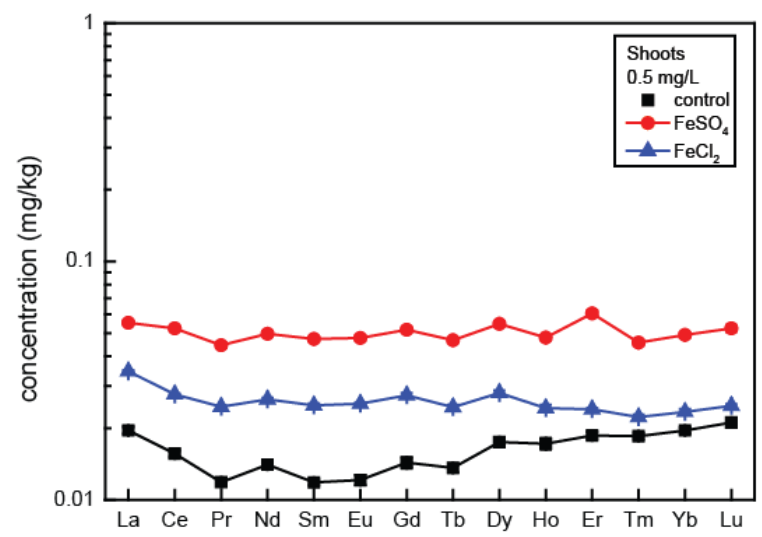

C

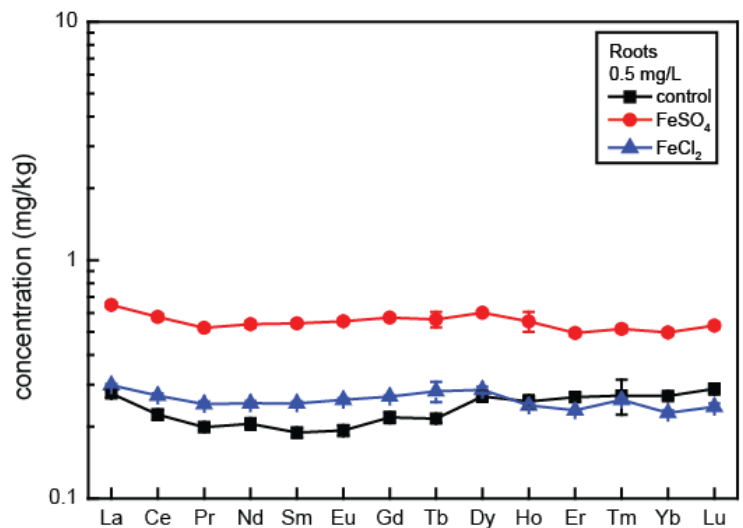

b
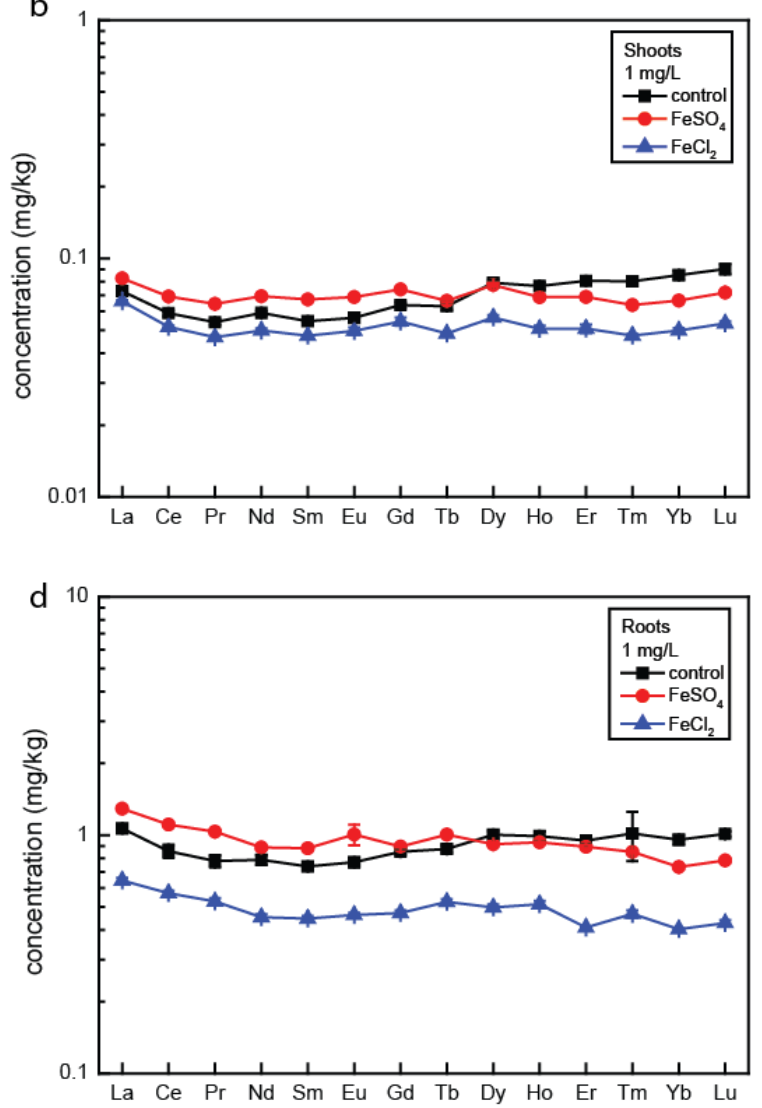

Fig. 5 Rare earth element patterns of shoots $(a, b)$ and roots $(c, d)$ at REE concentrations of 0.5 $\mathrm{mg} / \mathrm{L}$ and $1 \mathrm{mg} / \mathrm{L}$. Black square, red circle and blue triangle markers correspond to the control condition (no Fe(II) salts added), the Fe(II) sulfate and Fe(II) chloride experimental set-ups, respectively. 

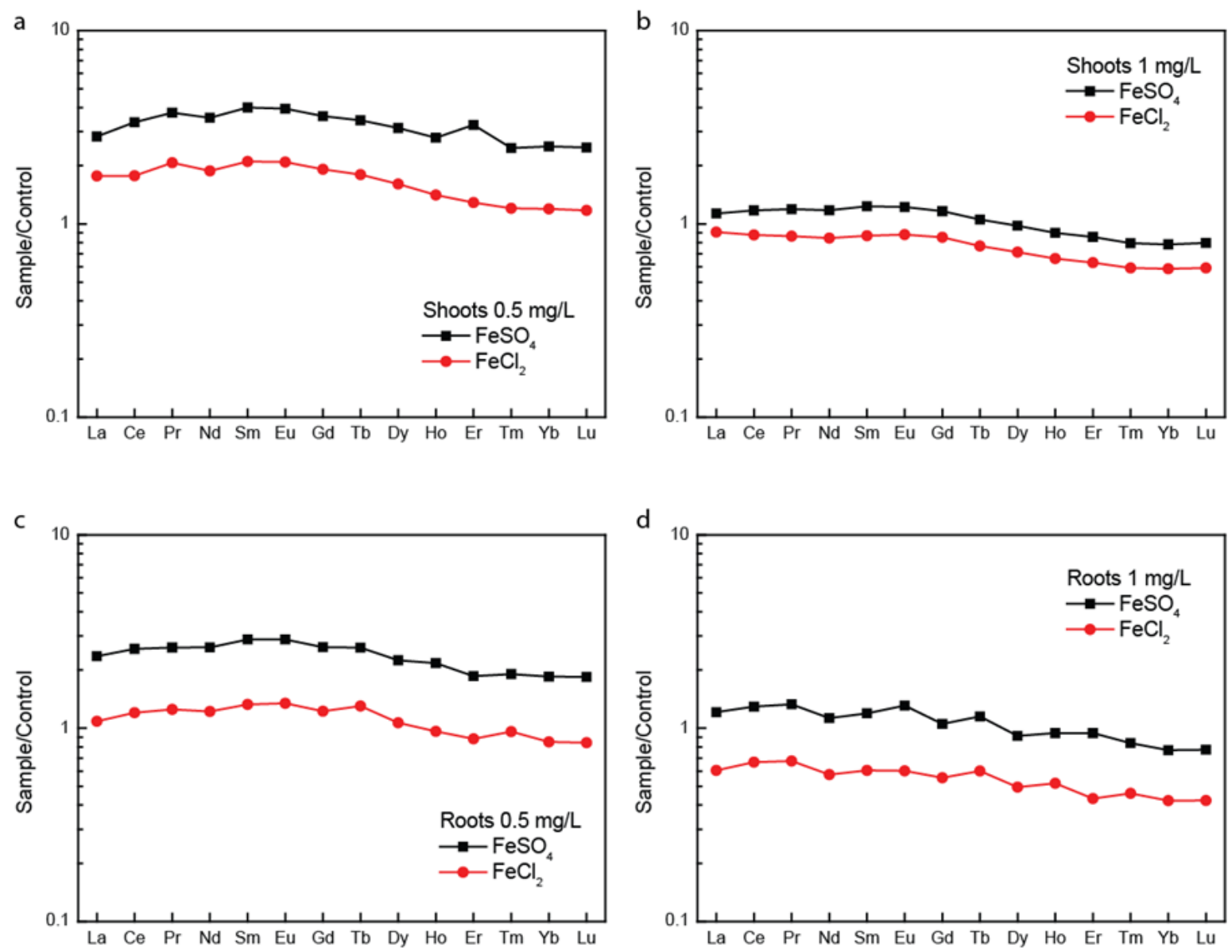

Fig. 6 Rare earth element patterns normalized to control experiment of shoots $(a, b)$ and roots (c,d) at REE concentrations of $0.5 \mathrm{mg} / \mathrm{L}$ and $1 \mathrm{mg} / \mathrm{L}$. Black square and red circle markers correspond to the $\mathrm{Fe}(\mathrm{II})$ sulfate and $\mathrm{Fe}(\mathrm{II})$ chloride experimental set-ups, respectively. 

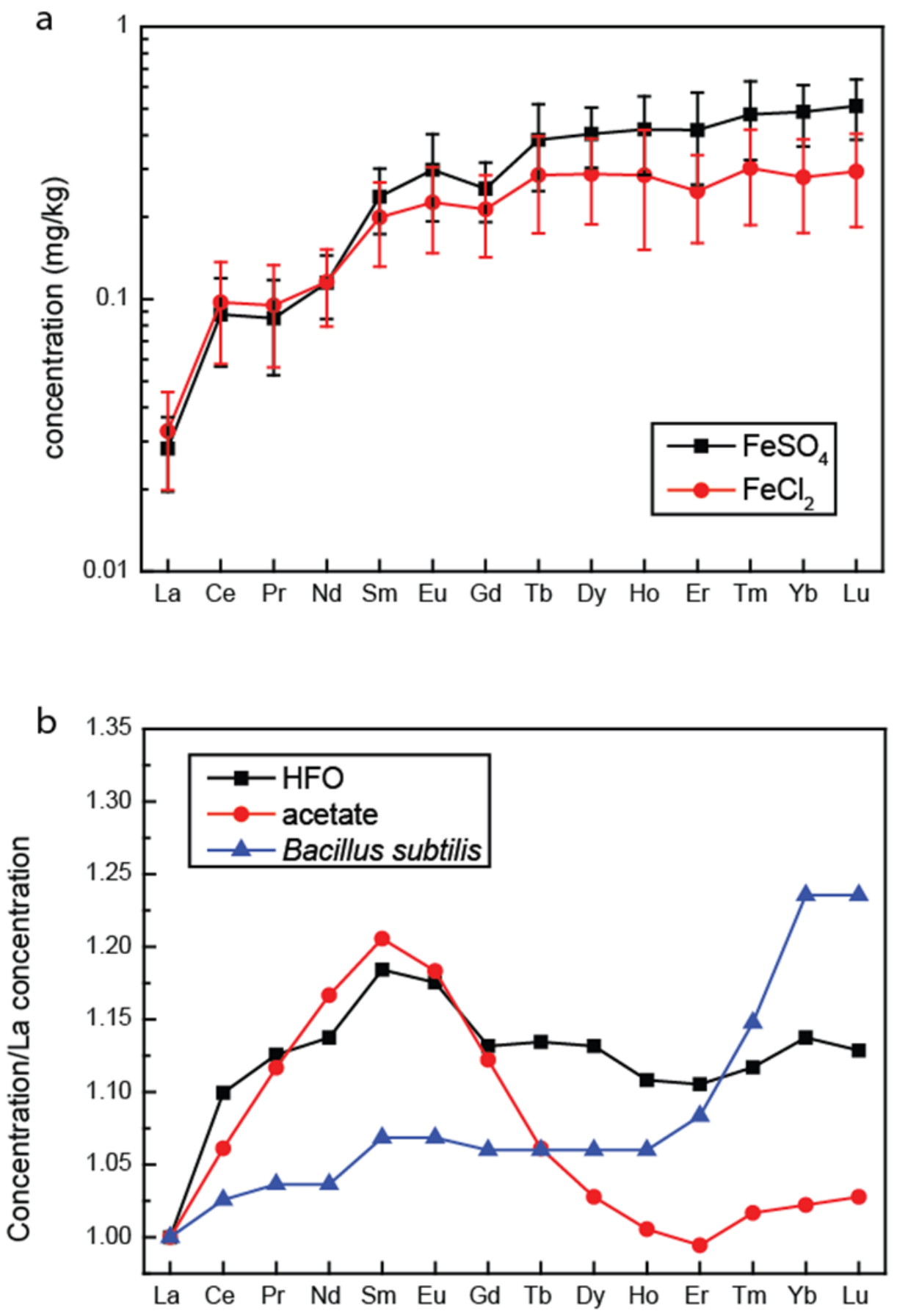

Fig. 7 Rare earth elements patterns of (a) iron plaques (Error bars are shown in the figure, $\mathrm{n}=2$ ) and (b) HFO, acetate and Bacillus subtilis from literature (Davranche et al., 2004; Byrne and Li, 1995; Martinez et al., 2014). Concentrations are normalized to La for comparison purpose. 


\section{Effect of rare earth elements on rice plant growth}

Raul E. Martinez ${ }^{1 *}$, Olivier Pourret ${ }^{2}$, Michel-Pierre Faucon $^{2}$, Charlotte Dian ${ }^{1}$

${ }^{1}$ Institute for Earth and Environmental Science, Albert-Ludwigs University, Albertstrasse 23B, 79104, Freiburg, Germany

${ }^{2}$ UniLaSalle, AGHYLE, 19 rue Pierre Waguet, 60026, Beauvais, France

Manuscript Highlights

1. Rare earth element affect the growth of rice plant roots and shoots.

2. The presence of sulfate increases the availability rare earth elements to the rice plant.

3. Iron (III) oxides, $\mathrm{Cl}^{-}$, and $\mathrm{SO}_{4}{ }^{2-}$ play a role in the REE fractionation and plant growth. 